\title{
Efficacy of select disinfectants at inactivating Ranavirus
}

\author{
Laura K. Bryan ${ }^{1}$, Charles A. Baldwin², Matthew J. Gray ${ }^{3}$, Debra L. Miller ${ }^{2,3, *}$ \\ ${ }^{1}$ University of Georgia, College of Veterinary Medicine, Athens, Georgia 30602, USA \\ ${ }^{2}$ Veterinary Diagnostic and Investigational Laboratory, University of Georgia, 43 Brighton Road, Tifton, \\ Georgia 31793-1389, USA \\ ${ }^{3}$ Center for Wildlife Health, Department of Forestry, Wildlife and Fisheries, University of Tennessee, \\ 274 Ellington Plant Sciences Building, Knoxville, Tennessee 37996-4563, USA
}

\begin{abstract}
Ranavirus can cause disease in reptiles and amphibians. Because survival time outside of a host remains uncertain, equipment must be disinfected to prevent transmission of ranaviruses. However, disinfectant efficacy against amphibian ranaviruses has not been investigated for chlorhexidine (Nolvasan ${ }^{\circledR}$ ), sodium hypochlorite (bleach), or potassium compounds. Our goal was to determine the efficacy of Nolvasan ${ }^{\circledR}(0.25,0.75$ and $2.0 \%)$, bleach $(0.2,1.0,3.0$ and $5.0 \%)$, and Virkon $\mathrm{S}^{\circledR}(1.0 \%)$ at inactivating Ranavirus at 1 and $5 \mathrm{~min}$ contact durations. Potassium permanganate $\left(\mathrm{KMnO}_{4}\right)(2.0$ and $5.0 \mathrm{ppm})$ was also tested with a 60 min contact time. Nolvasan ${ }^{\circledR}$ at 0.75 and $2.0 \%$ and bleach at 3.0 and $5.0 \%$ concentration were effective for both contact durations. Virkon $\mathrm{S}^{\circledR}$ was effective for both durations, but $\mathrm{KMnO}_{4}$ was not effective at either concentration. Concentrations of Nolvasan ${ }^{\circledR}$, bleach and Virkon $\mathrm{S}^{\circledR}$ that are at least $0.75,3.0$ and $1.0 \%$, respectively, are effective at inactivating Ranavirus after 1 min exposure time.
\end{abstract}

KEY WORDS: Ranavirus · Amphibians · Disinfection $\cdot$ Chlorhexidine $\cdot$ Pathogen pollution $\cdot$ Potassium peroxymonosulfate $\cdot$ Potassium permanganate $\cdot$ Sodium hypochlorite

Resale or republication not permitted without written consent of the publisher

\section{INTRODUCTION}

The genus Ranavirus encompasses several related double-stranded DNA icosahedral viruses of the family Iridoviridae. Ranaviruses cause disease in fish, reptiles and amphibians (Chinchar 2002, Converse \& Green 2005, Robert et al. 2007). Ranaviruses have been implicated in large-scale die-offs of amphibians in Europe, Asia, Australia, and the Americas (Converse \& Green 2005, Picco et al. 2007). In the United States, ranaviruses have been associated with significant amphibian losses in 15 states (Converse \& Green 2005). These mortality events have generated global concern for the welfare of amphibians. In May 2008, the World Organization for Animal Health (OIE) classified Ranavirus as a notifiable pathogen (OIE 2008), imposing guidelines for the importation of amphibians across international borders. There are no treatments or vaccinations currently available for ranaviruses (Robert et al. 2007).
Captive ranaculture and zoological facilities also have experienced large-scale morbidity and mortalities due to Ranavirus (Miller et al. 2007, D. L. Miller unpubl.). The United States imports an average of 14.7 million wild-caught amphibians a year and exports 2 million amphibians annually to markets in Europe and Asia (Schlaepfer et al. 2005). Most exported animals are held at several locations before reaching their final destination, and imported animals are dispersed widely throughout the United States (Schlaepfer et al. 2005). Commercial trade of amphibians for pets, research, bait and consumption has the potential to spread ranaviruses to naïve environments and new hosts (Picco et al. 2007). Recent phylogenic analyses found similarities between Ranavirus strains associated with mortality events and those isolated from infected amphibians used for food and bait, suggesting that environmental spread of ranaviruses may be linked to human recreation and 
commercial activities (Jancovich et al. 2005, Picco et al. 2007, Storfer et al. 2007).

Researchers and tourists may also spread ranaviruses by traveling between contaminated and uncontaminated areas. Overland transport of ranaviruses to new areas could occur via contaminated surfaces, such as hands, nets, shoes or other field equipment (Converse \& Green 2005). Fomite transmission has been linked to Ranavirus outbreaks in other aquatic species, including epizootic haematopoietic necrosis virus (EHNV) in redfin perch Perca fluviatilis (Langdon 1989). Langdon (1989) found that viral particles (virions) of EHNV remained infective for over 113 but less than $200 \mathrm{~d}$ on dry surfaces, and for at least $97 \mathrm{~d}$ in water. Because survival time of anuran ranaviruses remains uncertain outside the host, amphibian biologists, ranaculturalists and zoo personnel thoroughly disinfect equipment to prevent possible spread of Ranavirus to naïve populations (Fish and Wildlife Service 2008).

Disinfectants must be safe for use with amphibians and must inactivate a significant proportion of Ranavirus to be deemed effective. Efficacy is determined by quantifying the number of virions present in a sample after one application of the disinfectant, with an effective agent producing at least a $3 \log _{10}(99.9 \%$ inactivated) reduction in titer (Scott 1980, Environmental Protection Agency 2008). Chlorhexidine, sodium hypochlorite (bleach) and potassium compounds are the most common disinfectants used by field biologists and zoological facilities (Hadfield \& Whitaker 2005), but none of the 3 has been tested for its efficacy at inactivating Ranavirus. A $1.0 \%$ concentration of bleach is used to clean non-porous surfaces and is considered a safe concentration for use with amphibians (Hadfield \& Whitaker 2005). Current guidelines recommend bleach dilutions of up to $5.0 \%$ for disinfecting clothing, field equipment and containers (e.g. used to temporarily hold amphibians) for 10 to 15 min between animals (Fish and Wildlife Service 2008). Manufacturer's recommendations (Chlorox Bleach ${ }^{\circledR}$, The Chlorox Company) also suggest a $3.0 \%$ dilution of bleach for disinfecting hard surfaces and recommend at least $10 \mathrm{~min}$ of disinfectant contact time. Contact durations of over 10 min may be impractical for biologists, especially if a large number of specimens are handled. Further, bleach contact can be toxic to amphibians and it can damage equipment if used repeatedly or at high concentrations; thus high concentrations of bleach cannot be used.

Chlorhexidine is a bactericidal agent marketed as a general disinfectant for surgical instruments and veterinary equipment (Bailey \& Longson 1972). A $2.0 \%$ dilution of Nolvasan ${ }^{\circledR}$ (Fort Dodge Animal Health) with a 10 min contact time is recommended for disin- fecting inanimate objects per label instructions. Chlorhexidine is generally considered safe for use on amphibians at low concentrations $(0.75 \%)$ for short durations (Hadfield \& Whitaker 2005). Chlorhexidine is effective at inactivating enveloped viruses (Bailey \& Longson 1972, Scott 1980), but it is not effective against non-enveloped viruses (Bailey \& Longson 1972, Scott 1980, Royer et al. 2001). Ranaviruses can be infective both with and without the presence of a viral envelope (Chinchar 2002).

Potassium peroxymonosulfate compounds have been used as broad spectrum disinfectants in veterinary and aquaculture facilities (Danner \& Merrill 2006). Manufacturer's guidelines (Virkon S®, DuPont Animal Health Solutions) recommend a 1.0\% solution for disinfecting equipment with a $10 \mathrm{~min}$ contact time. Virkon $\mathrm{S}^{\circledR}$ is effective at inactivating both enveloped and non-enveloped viruses (Royer et al. 2001, Eleraky et al. 2002). However, the effect of Virkon $\mathrm{S}^{\circledR}$ on live amphibians is unknown. Potassium permanganate (KMnO4) is a similar oxidizing disinfectant, but it can also be used as a treatment for parasitic and bacterial infections of fish (Lio-Po \& Lim 2002). An accepted and safe short-term therapeutic dose of $\mathrm{KMnO}_{4}$ in fish is $5 \mathrm{mg} \mathrm{l}^{-1}$ for $60 \mathrm{~min}$ (Mashima \& Lewbart 2000). $\mathrm{KMnO}_{4}$ toxicity varies across aquatic species, with continuous exposure to dosages above $2.0 \mathrm{ppm}$ causing adverse effects in some individuals if the organic content of the water is low (Schachte 1983). The effect of $\mathrm{KMnO}_{4}$ on amphibian species has not been documented extensively, but Horié (1941) reported delayed metamorphosis and increased growth rate in $30 \%$ of common frog tadpoles, Rana temporaria, after exposure to $0.5 \mathrm{mg} \mathrm{l}^{-1} \mathrm{KMnO}_{4}$ over a period of $2 \mathrm{mo}$.

The objective of this study was to test the efficacy of chlorhexidine, sodium hypochlorite, potassium peroxymonosulfate and potassium permanganate solutions in inactivating Ranavirus at different concentrations and contact durations. Our goal was to identify an effective disinfectant for inactivating Ranavirus that will be safe to use with amphibians and aid in reducing pathogen transmission in captive and free-ranging environments.

\section{MATERIALS AND METHODS}

Our protocol for evaluating the virucidal qualities of each disinfectant was based on the procedures outlined by Scott (1980). The Ranavirus isolate (GenBank accession no. EF 101697) used for this study was recently obtained from a cultured American bullfrog Rana catesbeiana. Stock solutions contained $1 \times 10^{8}$ plaque forming units (PFU) per ml of virus and were 
grown in fathead minnow (FHM) cell culture lines at the University of Georgia Veterinary Diagnostic and Investigational Laboratory in Tifton, Georgia. The FHM cells had been stored in liquid nitrogen storage canisters at the diagnostic laboratory for more than $10 \mathrm{yr}$ and were still viable. Cells were grown in $75 \mathrm{~cm}^{2}$ flasks (Corning) in MEM (Gibco) with 10\% fetal bovine serum (FBS, HyClone). All cell and viral growth was done at room temperature $\left(22^{\circ} \mathrm{C}\right)$ in a dark cabinet. We tested the efficacy of different concentrations of $6.0 \%$ sodium hypochlorite product (Chlorox Bleach ${ }^{\circledR}$ ), $2.0 \%$ chlorhexidine product (Nolvasan ${ }^{\circledR}$ ), $20.4 \%$ potassium peroxymonosulfate product (Virkon $\mathrm{S}{ }^{\circledR}$ ), and $\mathrm{KMnO}_{4}$ at inactivating Ranavirus (Table 1). Experimental concentrations of each disinfectant were formulated to $2 \times$ the final dilution and mixed with an equal amount $(2.5 \mathrm{ml})$ of a $1 / 5$ dilution of stock Ranavirus in MEM. Therefore, in the final mixture, the virus had already been diluted $10^{-1}$ from the original $1 \times 10^{8}$, resulting in a concentration of $1 \times 10^{7} \mathrm{PFU} \mathrm{ml}{ }^{-1}$. The virus-disinfection mixture was allowed to incubate for either 1 or $5 \mathrm{~min}$ at room temperature. The sample mixture was processed immediately through gel filtration columns at the end of each incubation period. A sample with disinfectant mixed with an equal amount of media and no virus was similarly processed in duplicate and served as the disinfectant control.

Gel filtration was accomplished by a double centrifuge tube apparatus consisting of an inner $30 \mathrm{ml}$ tube surrounded by an outer $50 \mathrm{ml} \mathrm{v}$-bottomed centrifuge tube as described by Blackwell \& Chen (1971) and Scott (1980). In brief, the $30 \mathrm{ml}$ tube was perforated at the bottom and a cotton pledget securely inserted into the hole. Both components were sterilized via autoclave before assembly of the gel column. A slurry of 22:78 phosphate buffered saline solution and expanded Sephadex ${ }^{\mathrm{TM}}$ LH-20 gel solution (GE Healthcare Bio-Sciences) was prepared and $25 \mathrm{ml}$ of slurry was transferred into each $30 \mathrm{ml}$ tube. Excess filtrate was removed by centrifugation at $4^{\circ} \mathrm{C}$ at $200 \times g$ for $10 \mathrm{~min}$ until the gel column was firmly packed. Trans- fer of gel was conducted under sterile conditions and care was taken not to contaminate the $50 \mathrm{ml}$ collection tube.

Each gel filtration apparatus was cooled to $4{ }^{\circ} \mathrm{C}$ before use. After the disinfectant-virus mixtures had reacted for the allotted time, each lot of mixture was poured into the $30 \mathrm{ml}$ tube and centrifuged at $200 \times g$ for $10 \mathrm{~min}$ at $4^{\circ} \mathrm{C}$. Residual virus moved through the gel and was collected in the $50 \mathrm{ml}$ tube. Disinfectant residues remained within the gel fraction and were not collected with the virus filtrate. We also processed samples of disinfectants without Ranavirus through the columns to rule out cell toxicity due to residual disinfectant. The FHM cell cultures were seeded onto 6well plastic culture plates (Becton Dickinson) and allowed to form a complete monolayer prior to use, usually requiring a period of $24 \mathrm{~h}$. Plaque assays were conducted using the filtrate from the centrifuged control and treated samples. Ten-fold viral dilutions from $10^{-2}$ to $10^{-8}$ of each filtrate were prepared using viral media in a ratio of $0.5 \mathrm{ml}$ sample to $4.5 \mathrm{ml}$ medium. Five hundred $\mu \mathrm{l}$ aliquots of each serial dilution were placed on the culture plates in duplicate with 2 wells inoculated with media only to serve as the negative virus control.

Culture plates were incubated for $1 \mathrm{~h}$ at room temperature, with gentle rocking every $15 \mathrm{~min}$ to disperse the inoculum during the incubation period, after which excess media was removed from all wells. Each well was overlaid with $5 \mathrm{ml}$ of a mixture of equal parts $2 \times$ basal medium Eagle with Earle's salts (BME/EBSS, Mediatech) and 1.50\% carboxymethyl cellulose (CMC, Sigma-Aldrich), with $5.0 \%$ FBS added to maintain FHM cells. This mixture produced a final concentration of $1 \times$ BME/EBSS and $0.75 \%$ CMC. The $1 \times$ BME/EBSS was produced by dissolving $18.38 \mathrm{~g}$ of BME/EBSS media in $1000 \mathrm{ml}$ of distilled water, stirring until the mixture was completely dissolved and filtering through a $0.2 \mu \mathrm{m}$ filter to sterilize (Nalgene). The CMC was produced by dissolving $1.5 \mathrm{~g} \mathrm{CMC}$ in $100 \mathrm{ml}$ of distilled water. The mixture was heated and stirred continuously until completely

Table 1. Experimental concentrations (\%) of disinfectants used to test for efficacy against Ranavirus. Parenthetical values indicate the concentration (\%) of active ingredient in each solution. NA: not applicable; either not done or no known concentration to test

\begin{tabular}{|c|c|c|c|c|c|}
\hline Disinfectant & $\begin{array}{c}\text { Active } \\
\text { ingredient }\end{array}$ & $\begin{array}{c}\text { Most } \\
\text { dilute } \\
\text { concentration }\end{array}$ & $\begin{array}{l}\text { Recommended } \\
\text { concentration for } \\
\text { amphibians }\end{array}$ & $\begin{array}{l}\text { Manufacturer's } \\
\text { recommended } \\
\text { concentration }\end{array}$ & $\begin{array}{c}\text { Most } \\
\text { concentrated }\end{array}$ \\
\hline Bleach (6.0) & Sodium hypochlorite & $0.20(0.012)$ & $1.00^{\mathrm{a}}(0.060)$ & $3.00(0.180)$ & $5.00^{\mathrm{b}}(0.300)$ \\
\hline Nolvasan ${ }^{\circledR}(2.0)$ & Chlorhexidine & $0.25(0.005)$ & $0.75^{\mathrm{a}}(0.015)$ & $2.00(0.040)$ & NA \\
\hline Virkon $\mathrm{S}^{\circledR}(20.4)$ & Potassium peroxymonosulfate & NA & NA & $1.00(0.204)$ & NA \\
\hline $\mathrm{KMnO}_{4}(100)$ & Potassium permanganate & 0.00020 & NA & None & 0.00050 \\
\hline
\end{tabular}


dissolved. The CMC was sterilized by autoclaving for $15 \mathrm{~min}$ at $121^{\circ} \mathrm{C}$. Inoculated plates were incubated for $6 \mathrm{~d}$ at room temperature. Cultures were stained with $5 \mathrm{ml}$ of $0.1 \%$ crystal violet in $10.0 \%$ neutral buffered formalin once plaques had formed. Occasionally, plaques could be visualized by the naked eye; however mostly they were visualized by placing the plates on an inverted microscope. Stains were allowed to set for a minimum of 10 min after which excess stain was removed and the plates gently washed with tap water. After the plates dried, plaques present in the wells were counted and the PFU per ml titers were calculated for both the treated and control samples. This consisted of counting the plaques in the well, and by using the dilution of the disinfectant-virus dilution of that well. The PFUs per ml counts were then converted to total PFUs in one $\mathrm{ml}$. The $\log _{10}$ difference in titer between control and experimental samples was considered the amount of virus inactivated by the disinfectants. Current

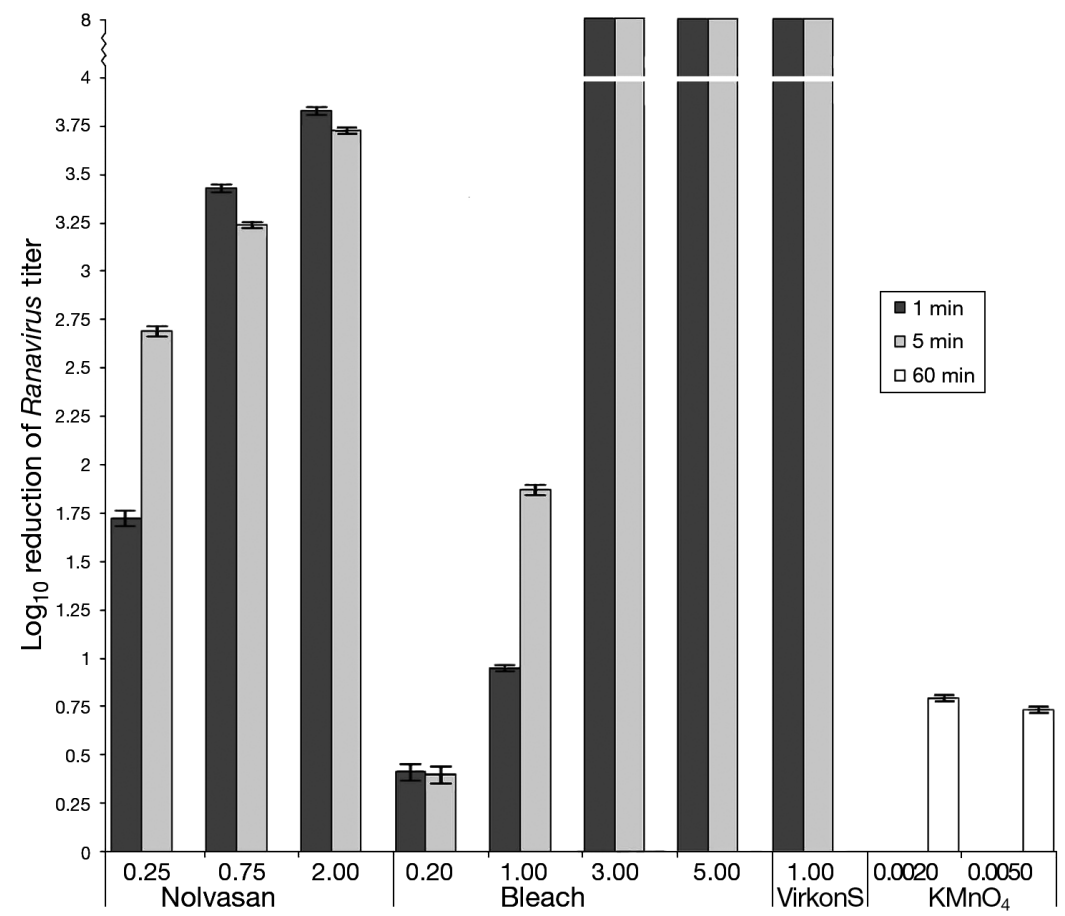

Fig. 1. $\log _{10}$ reductions in Ranavirus titer from chlorhexidine (Nolvasan ${ }^{\circledR}$ ), sodium hypochlorite (bleach), potassium peroxymonosulfate (Virkon $\mathrm{S}^{\circledR}$ ) and potassium permanganate $\left(\mathrm{KMnO}_{4}\right)$ addition for different concentrations $(\%)$ and exposure durations. $\log _{10}$ reductions $\geq 3$ indicate at least $99.9 \%$ inactivation of Ranavirus. Error bars represent standard deviation from the mean disinfection protocols for non-porous surfaces (Environmental Protection Agency 2008) and previous disinfectant efficacy studies (Scott 1980, Royer et al. 2001) recommend at least a $3 \log _{10}$ reduction in viral titer (99.9\% inactivated) for a disinfectant to be considered effective.

\section{RESULTS AND DISCUSSION}

The 0.75 and $2.0 \%$ Nolvasan ${ }^{\circledR}$ concentrations were effective at inactivating Ranavirus at 1 and $5 \mathrm{~min}$ (Fig. 1). The greatest reduction in viral titer was achieved with 3.0 and $5.0 \%$ bleach at 1 and 5 min (Fig. 1). Neither the $0.25 \%$ Nolvasan ${ }^{\circledR}$ concentration nor the 0.20 or $1.0 \%$ bleach concentrations were effective at either reaction time. Virkon $\mathrm{S}^{\circledR}$ was effective at both 1 and $5 \mathrm{~min} . \mathrm{KMnO}_{4}$ was not effective at inactivating Ranavirus at either 2.0 or $5.0 \mathrm{ppm}$. In all of the disinfectant controls, no toxicity to the monolayers due to the action of the disinfectant was observed.

Concentrated disinfectant solutions and long contact duration times are not necessary to inactivate Ranavirus. Nolvasan ${ }^{\circledR} 0.75 \%$ at 1 min was the lowest disinfectant concentration and shortest time necessary to reach a $3 \log _{10}$ reduction in Ranavirus titer. Expo-

sure to $3.0 \%$ bleach for 1 min was as effective as $5.0 \%$ bleach for 1 min at inactivating Ranavirus. Virkon $\mathrm{S}^{\circledR}$ completely reduced viral titer at $1.0 \%$ concentration and was equally effective at both time frames. In general, weaker disinfectant concentrations are less harmful to the environment and are less damaging to equipment. In addition, lower disinfectant concentrations and shorter contact durations also reduce exposure of amphibians to potentially toxic levels of disinfectant. Thus, the $0.75 \%$ Nolvasan ${ }^{\circledR}$ solution may be more ideal than using either $3.0 \%$ or $5.0 \%$ bleach in most situations. Since toxicity of $1.0 \%$ Virkon $\mathrm{S}^{\circledR}$ to amphibians has not been determined, direct contact between disinfectant and amphibians should be avoided until its safety has been thoroughly tested.

Our Nolvasan ${ }^{\circledR}$ results are similar to previous disinfectant efficacy studies involving enveloped viruses. Bailey \& Longson (1972) reported a 5 to $6 \log _{10}$ reduction in titer of human herpesvirus when exposed to $1.0 \%$ Nolvasan ${ }^{\circledR}$ for 90 min. Scott (1980) also reported a $5 \log _{10}$ inactivation of feline herpesvirus after applying $0.78 \%$ Nolvasan ${ }^{\circledR}$ for 10 min. The slightly lower reduction in viral titer in our study could be attributed to shorter contact durations.

Previous studies evaluating the effectiveness of bleach on enveloped viruses have reported similar 
reductions in viral load. Scott (1980) reported a $5 \log _{10}$ reduction in titer of feline herpesvirus when using a $3.0 \%$ bleach concentration for $10 \mathrm{~min}$. Similarly, Langdon (1989) reported a complete inactivation of EHNV virions after application of a $200 \mathrm{mg}$ liter $^{-1}$ sodium hypochlorite solution (equivalent to a $3.3 \%$ bleach concentration) to cell culture for $2 \mathrm{~h}$. Thus, Nolvasan ${ }^{\circledR}$ and bleach appeared to be effective at inactivating an amphibian Ranavirus similar to other enveloped viruses.

Our results with Virkon $\mathrm{S}^{\circledR}$ are similar to those reported by previous studies involving enveloped viruses. Eleraky et al. (2002) reported a complete $\left(5 \log _{10}\right)$ reduction in titer of feline herpesvirus when exposed to $1.0 \%$ Virkon $S^{\circledR}$ for $10 \mathrm{~min}$. Our results produced a total reduction $\left(8 \log _{10}\right)$ in Ranavirus titer, but after only $1 \mathrm{~min}$ exposure to the disinfectant. $\mathrm{KMnO}_{4}$ was not an effective disinfectant against Ranavirus, producing less than a $1 \log _{10}$ reduction in titer for both tested concentrations at a contact time of 60 min. In contrast, Hatori et al. (2003) documented a total reduction in titer of Oncorhynchus masou virus, a herpesvirus, after a $20 \mathrm{~min}$ application of $16 \mathrm{ppm}$ $\mathrm{KMnO}_{4}$. These differences may be due to differences in the envelopes of ranaviruses and herpesviruses, or more likely due to the greater concentration (16 ppm) of $\mathrm{KMnO}_{4}$ used in the previous study.

Two additional caveats should be considered when applying our results to field situations. First, the concentration of Ranavirus used in our study was $1 \times 10^{8}$ PFU ml $\mathrm{m}^{-1}$, which may not represent an environmentally relevant concentration. Data on Ranavirus concentrations in the environment are not available; however, Rojas et al. (2005) reported that shedding of Ranavirus by infected individuals was $10^{3}$ to $10^{4} \mathrm{PFU}$ $\mathrm{ml}^{-1}$. Others have used dose concentrations of $1 \times$ $10^{3} \mathrm{PFU} \mathrm{m} \mathrm{m}^{-1}$ in experimental challenge studies, because this concentration has been shown to cause mortality in several amphibian species (Pearman et al. 2004, Brunner et al. 2007, Schock et al. 2008). Given that our viral concentration exceeds levels known to induce amphibian mortality and is at a level possibly higher than expected in the environment, our results are likely to be applicable for most environmental and laboratory situations. Second, the efficacy of the tested disinfectants at Ranavirus inactivation when organic or inorganic materials (e.g. vegetation, soil) are present is unknown. Thus, we recommend that field biologists wash organic matter and soil from equipment to help ensure contact of infectious virus particles with any applied disinfectants. The effect of soil and other organic material on disinfectant efficacy needs to be tested. Environmental persistence of ranaviruses on various substrates also should be studied.
Finally, other chemicals often are used by field biologists and ranaculture and zoological facilities, and their efficacy at amphibian Ranavirus inactivation should be tested before they are used. For example, formalin (150 to $250 \mathrm{ppm}$ ) has been used to treat external parasitic infections in fish (Lio-Po \& Lim 2002). Ethanol is commonly used by field biologists to preserve specimens and has been reported to be effective at inactivating EHNV virions (Langdon 1989). None of these chemicals have been evaluated for inactivation of amphibian Ranavirus virions, but if effective, they may prove to be a suitable alternative to Nolvasan ${ }^{\circledR}$, bleach, and potassium compounds.

Acknowledgements. The authors thank M. Byrd and D. Ingram for cell culture preparation and the rest of the staff of the Veterinary Diagnostic and Investigational Laboratory (VDIL) for their assistance. This study was sponsored and funded by the Georgia Veterinary Scholars program, MerckMerial and the VDIL.

\section{LITERATURE CITED}

Bailey A, Longson M (1972) Virucidal activity of chlorhexidine on strains of Herpesvirus hominis, poliovirus, and adenovirus. J Clin Pathol 25:76-78

Blackwell JH, Chen JHS (1971) Effects of various germicidal chemicals on H.Ep. 2 cell culture and herpes simplex virus. J AOAC Int 53:1229-1236

> Brunner JL, Schock DM, Collins JP (2007) Transmission dynamics of the amphibian ranavirus Ambystoma tigrinum virus. Dis Aquat Org 77:87-95

Chinchar VG (2002) Ranaviruses (family Iridoviridae): emerging cold-blooded killers: brief review. Arch Virol 147:447-470

Converse KA, Green DE (2005) Diseases of tadpoles. In: Majumdar SK, Huffman JE, Brenner FJ, Panah AI (eds) Wildlife diseases: landscape epidemiology, spatial distribution and utilization of remote sensing technology. Pennsylvania Academy of Science, Easton, PA, p 72-88

Danner GR, Merrill P (2006) Disinfectants, disinfection and biosecurity in aquaculture. In: Scarfe D, Lee C, O'Bryen PJ (eds) Aquaculture biosecurity: prevention, control, and eradication of aquatic animal disease. Blackwell Publishing Professional, Boston, MA, p 91-128

Eleraky NZ, Potgieter LND, Kennedy MA (2002) Virucidal efficacy of four new disinfectants. J Am Anim Hosp Assoc 38:231-234

Environmental Protection Agency (2008) Protocol \# 01-1A: Protocol for residual self-sanitizing activity of dried chemical residues on hard, non-porous surfaces. EPA, Washington, DC. Www.epa.gov/oppad001/cloroxpcol_ final.pdf (Accessed 29 July)

Fish and Wildlife Service (2008) Abnormal amphibian monitoring: other standard operating procedures. FWS, Washington, DC. www.fws.gov/contaminants/Amphibian/ OtherSOPs.html\#BIOSAFE (Accessed 14 August, 2008)

Hadfield CA, Whitaker BR (2005) Amphibian emergency medicine and care. Semin Avian Exot Pet Med 14:79-89

Hatori S, Motonishi A, Nishizawa T, Yoshimizu M (2003) Virucidal effect of disinfectants against Oncorhynchus masou virus (OMV). Fish Pathol 38:185-187 
Horié H (1941) Effects of potassium permanganate on the tadpoles of Rana temporaria. Proc Imperial Acad 17:83-86

Jancovich JK, Davidson EW, Parameswaran N, Mao J, Chinchar VG, Collins JP (2005) Evidence for emergence of an amphibian iridoviral disease because of human-enhanced spread. Mol Ecol 14:213-224

Langdon JS (1989) Experimental transmission and pathogenicity of epizootic haematopoietic necrosis virus (EHNV) in redfin perch, Perca fluviatilis L., and 11 other teleosts. J Fish Dis 12:295-310

Lio-Po GD, Lim LHS (2002) Infectious diseases of warmwater fish in fresh water. In: Woo PTK, Bruno DW, Lim LHS (eds) Diseases and disorders of finfish in cage culture. CABI Publishing, New York, p 231-281

Mashima TY, Lewbart GA (2000) Pet fish formulary. In: Fronfield SA (ed) The veterinary clinics of North America: exotic animal practice therapeutics, Vol 3(1). WB Saunders, Philadelphia, PA, p 117-130

Miller DL, Rajeev S, Gray MJ, Baldwin C (2007) Frog virus 3 infection, cultured American bullfrogs. Emerg Infect Dis $13: 342-343$

OIE (2008) OIE Aquatic Animal Health Code, Chapter 2.4.2. OIE, Paris. www.oie.int/eng/normes/fcode/en_chapitre 2.4.2.htm (Accessed 22 July, 2008)

Pearman PB, Garner TWJ, Straub M, Greber UF (2004) Response of the Italian agile frog (Rana latastei) to a Ranavirus, Frog virus 3: a model for viral emergence in naïve populations. J Wildl Dis 40:660-669

Editorial responsibility: Alex Hyatt, Geelong, Victoria, Australia
Picco AM, Brunner JL, Collins JP (2007) Susceptibility of the endangered California tiger salamander, Ambystoma californiense, to ranavirus infection. J Wildl Dis 43:286-290

> Robert J, Abramowitz L, Gantress J, Morales HD (2007) Xenopus laevis: a possible vector of Ranavirus infection. J Wildl Dis 43:645-652

Rojas S, Richards K, Jancovich J, Davidson E (2005) Influence of temperature on Ranavirus infection in larval salamanders Ambystoma tigrinum. Dis Aquat Org 63:95-100

Royer RL, Nawagitgul P, Halbur PG, Paul PS (2001) Susceptibility of porcine circovirus type 2 to laboratory and commercial disinfectants. J Swine Health Prod 9:281-284

Schachte JH (1983) Columnaris disease. In: FP Meyer, JW Warren, TG Carey (eds) A guide to integrated fish health management in the Great Lakes basin. Great Lakes Fishery Commission, Ann Arbor, MI, p 199-203.

Schlaepfer MA, Hoover C, Dodd CK (2005) Challenges in evaluating the impact of the trade in amphibians and reptiles on wild populations. BioScience 55:256-264

Schock DM, Bollinger TK, Chinchar VG, Jancovich JK, Collins JP (2008) Experimental evidence that amphibian ranaviruses are multi-host pathogens. Copeia 133-143

Scott FW (1980) Virucidal disinfectants and feline viruses. Am J Vet Res 41:410-414

Storfer A, Alfaro ME, Ridenhour BJ, Jancovich JK, Mech SG, Parris MJ, Collins JP (2007) Phylogenetic concordance analysis shows an emerging pathogen is novel and endemic. Ecol Lett 10:1075-1083

Submitted: September 23, 2008; Accepted: January 20, 2009 Proofs received from author(s): March 27, 2009 